\title{
Nationality (Justice and Crime Coverage)
}

\section{AUTHOR}

Franziska Oehmer

\section{KEYWORDS}

judicial reporting, court reporting, crime reporting, media ethics

\section{BRIEF DESCRIPTION}

The variable provides information on whether the nationality of the (alleged) victims and/or perpetrator is mentioned in connection with crimes and offences. Research shows that minorities are disproportionately more often depicted as perpetrators than as victims (Hestermann, 2010; Vinson \& Ertter, 2002).

\section{FIELD OF APPLICATION/THEORETICAL FOUNDATION} The variable "nationality of the (alleged) victim or perpetrator" is of particular relevance in the context of debates on media ethics and legal philosophy. It is mainly used in the field of media effects research (stereotype and cultivation research, see Arendt, 2010).

\section{EXAMPLE STUDY}

Hestermann (2010)

\section{INFO ABOUT VARIABLE}

Variable name/definition: nationality [Nationalität]

Level of analysis: mentioned (alleged) victim and perpetrator in the report

Values: Nationality of the victim \& perpetrator

- Nicht genannt

- Deutsch

- Ausländisch

- Ausdrücklich unbekannt

- Trifft nicht zu
Intercoder reliability: Nationality of the victim 0.94; Nationality of the perpetrator 0.98 (2 Coder). What exact coefficient has been calculated has not been reported.

Codebook: available at https://www.jstor.org/stable/j.ctv941tf9.12

\section{REFERENCES}

Arendt, F. (2010). Cultivation effects of a newspaper on reality estimates, explicit and implicit attitudes. Journal of Media Psychology, 22, 147-159.

Hestermann, T. (2010). Fernsehgewalt und die Einschaltquote: Welches Publikumsbild Fernsehschaffende leitet, wenn sie über Gewaltkriminalität berichten. Baden-Baden: Nomos Verlagsgesellschaft mbH. [Television violence and ratings: Which picture of the audience leads television makers when they report on violent crime].

Vinson, C. D., \& Ertter, J. S. (2002). Entertainment or Education: How Do Media Cover the Courts? Harvard International Journal of Press/Politics, 7(4), S. 80-97. 